\title{
Study on the strategy of rural tourism development under the
}

\section{background of beautiful countryside construction}

\author{
Hui-ying CHEN \\ School of Arts and Communications, \\ Wuhan Polytechnic University, Wuhan, Hubei, 430023, China
}

\begin{abstract}
Keywords: Beautiful countryside construction; Rural tourism; Development strategy
\end{abstract}
Abstract: the rapid development of rural tourism not only meets the changing consumer demand of tourism consumers, but also provides a new breakthrough point for the new rural construction in twenty-first Century, and the proposal of "beautiful countryside construction" gives new connotation and new ideas for the sustainable development of rural tourism. Based on the beautiful countryside construction, this paper analyzes the characteristics of rural tourism development under the background of beautiful countryside construction, and puts forward the development strategy of rural tourism under the background of beautiful countryside construction.

\section{Introduction}

From 2016 onwards, the central government in accordance with each village of 1 million 500 thousand a year, two years of continuous support plan, "13th Five-Year" during the country built around 6000 beautiful countryside, the beautiful countryside construction, society and government should play the role of the market, and promote the construction of the beautiful countryside, need to rural tourism based on the construction of the beautiful countryside tourism industry chain to explore the development strategy of rural tourism.

\section{Characteristics of rural tourism development under the background of beautiful countryside construction}

Regional resources. The development pattern of regional tourism resources based mainly refers to the resources in rural areas and farmers Home Furnishing Agriculture Forestry Animal Husbandry and fishery and garden as the carrier of rural tourism, including the main types of rural landscape, rural culture and life of farmers based "farm", in order to enrich the unique rural tourism resources and the traffic condition based "tourist town and village in the original ecological and historical Folk Culture Village Tour Based"". For example, Chengdu's "Nongjiale", the main features of type base for rural production "farmhouse garden", to view the spring peach (pear) flowers, fresh flowers and summer tours "sightseeing orchard", in Dujiangyan and other scenic spots as the representative of the "Scenic Hotel", in addition to farming science, houses type, type of farming experience. The tourism town is mainly represented by the south of the Yangtze River. "Village Tour" is based on the unique culture and customs of the village, and develops tourism activities according to circumstances, forming a development mode.

Take development and management as the guidance. With the development and operation of the main mode of development oriented, which is mainly divided by property right organization form, including in Wuhan District of Huangpi City, "four main development" mode as the representative of the government led development drive mode; due to the objective existence of its geographical 
location, only through the transformation of external traffic conditions to achieve, in the government and enterprise driven by farmers' participation in development, comprehensive development mode of Community Management Department of tourism development of the whole process of standardization, supervision and management, namely "government + enterprise + community + farmers"; the introduction of economic strength and market operation ability of the enterprise, the enterprise financial strength and management experience, the main business of investment and operation "company + farmers" model of development, especially the strong and attractive tourism resources in the scenic areas such as Yunnan, Guizhou; the development of rural tourism products, pipe The development of tourism, agriculture, industry and commerce, which is dominated by rural tourism, is also a development mode of sales process. It also includes the combination of agriculture and tourism, resources and environment community participation -economic development, management and monitoring and continuous regulation mode (ER-S- E- M continuous regulation mode).

On the basis of product project. Tourism product project type as the development model is mainly used in the theme of rural tourist attractions. The six main elements of tourism are the breakthrough points for the development of rural theme projects. The development mode of the most typical ornamental and participation for recreation and sightseeing, science, such as the Wuhan agricultural carnival, New Zealand tourism garden; with authentic local folk customs based folk experience; according to the rural environment and ecological landscape to create high-grade tourism infrastructure resort business; the use of information network technology to provide services of rural tourism rural tourism club full of tourists, as an intermediary or information center for connecting services for tourists, such as ordering tourist routes. In addition to the new experience based tourism development mode, regional and rural landscape artistic conception in the dream experience, different time and space, to create a variety of dynamic natural phenomena or artistic conception of tourist types, such as country representative - Linhai conception.

\section{The strategy of rural tourism development under the background of beautiful countryside construction}

Relying on innovative tourism resources. Most areas of development of rural tourism in our country are based on the traditional agriculture resources, tourism resources has led to great similarity, tourism products tend to be homogeneous, so must excavate the traditional cultural resources, cultivate new tourism resources, especially the green and ecological tourism resources. The core competitiveness of rural tourism development is the original and true rural culture, rural tourism culture is rooted in the rural network, natural and historical background, and the country's natural and cultural history, is consistent, therefore, excavate the cultural connotation of rural tourism is the key to the sustainable development of rural tourism. The cultivation of new tourism resources including technology based and event based; technical support is mainly based on the use of modern technology, industrial integration, to create a reflected rural tourism landscape characteristics, such as the real version of the "Happy Farm Festival"; depending on the planning of tourism festivals, such as the United States on festival tourism festival activities and development of Pumpkin Festival, Strawberry Festival, cherry festival, festival, festival and other rural garlic burger.

Expand the main body of development and management. Rural tourism development should choose the most suitable management form according to the local actual situation, and achieve multi win in the premise of guaranteeing the interests of the rural community residents. The 
development of rural tourism management main body is most of the government or enterprises as the main body, household and community participation, on the basis of this, should be the development of farmers for the main business of community participation play a key function, can follow the French construction of "farmers + enterprise + community + government", the development of rural tourism must be reasonable in planning to maintain the original rural landscape on the basis of the farmers as rural tourism operators, can guarantee the sustainability of rural tourism and authenticity. As the enterprise support system, funding and management concept for the development of the Rural Tourism Association, the development of industry specifications and quality standards of rural tourism in the government's policy guidance, promote industry self-regulation, and serves as a community tourism association plays an important role in the sustainable development of tourism, the government from the angle of law to regulate the market and provide preferential policies for rural tourism.

Rich product project themes. Rural tourism products should pay attention to the authenticity, experience, diversity, rural tourism product innovation projects mainly in the form of innovation, the type of innovation and function innovation; innovative products form is mainly reflected rural local characteristics, creating a country project experience, such as Jiangnan Wuzhen dyeing workshop, let the tourists to participate in the process of making cloth in France; Wine village, tourists visit the countryside through the vineyards and wine workshop, participate in the whole process Wine brewing, brewing process, to understand the history and culture Wine. The innovation of the type is based on the existing tourism resources, and according to the market dynamics, we should build new product development models, such as Country Village Hotel in Spain and Singapore's Agricultural Science Park. The innovation of the function is to dig deep and develop the function of rural tourism, and to meet the changing consumption demand of the tourists. In the embodiment of tourism product interaction, cultural characteristics should also reflect the ecological, so pay attention to the protection of the rural ecological environment at the same time of product innovation, such as the type of recreation tourism products to provide low carbon activities, can also provide a "low carbon tree" to allow visitors to planting, increase its entertainment.

\section{Reference}

[1] Bai Congxia. Analysis of rural tourism development model [J]. Shanxi architecture, 2012, 38 (2): 16-17

[2] Li Deming, Cheng Jiumiao. The interaction of rural tourism and economy sustainable development pattern and countermeasures [J]. Human geography, 2005 (3): 84-87

[3] Ma Yong, Zhao Lei, Song Hong, Guo Qingxia, Liu Mingjian. China's rural tourism development path and mode -- take Chengdu rural tourism development mode as an example, [J]. economic geography, 2007,27 (2):336-339

[4] Zheng Yan, Li Qinglei. Research on the innovation of rural tourism development model under the new situation [J]. Anhui agricultural science, 2011, 39 (13): 7961-7963

[5] Guo Jing, haunso. A study on the development strategy of modern rural tourism from the perspective of cloud tourism [J]. Journal of Xi'an University of Posts and Telecommunications, 2012, 17 (5):108-111 